\title{
Knowledge and practice on adequate sunlight exposure of infants among mothers attending EPI unit of Aleta Wondo Health Center, SNNPR, Ethiopia
}

\author{
Asres Bedaso ${ }^{*}$ (D), Melese Gebrie, Bedilu Deribe, Mohammed Ayalew and Bereket Duko
}

\begin{abstract}
Objective: The main objective of this study was to assess knowledge and practice of adequate sunlight exposure of infants among mothers attending EPI unit at Aleta Wondo Health Center, Sidama zone, SNNPR, Ethiopia. Institutional based descriptive cross sectional study design was used. 313 mothers who had under 1 year child and immunization follow-up were selected by simple random sampling technique using immunization registration book as sampling frame.

Result: Out of 313 respondents identified for the study $98.03 \%(n=307)$ were responded for the interview. From the total respondents 279 (90.9\%) of respondents exposed their infants to sunlight but only 62 (22\%) of them exposed adequately. From 307 mothers, 191 (62.2\%) are knowledgeable about sunlight exposure and 91 (32.6\%) of mothers had good practice of exposing their infants to sunlight.
\end{abstract}

Keywords: Sunlight exposure, Mothers' knowledge, Mothers practice, Vitamin D

\section{Introduction}

Sunlight exposure has a lots of health benefits for infants, it helps the body to produce vitamin D that helps the body to absorb calcium [1]. Also has a function of strengthening bones thereby preventing rickets in children and osteomalacia in adults and possibly inhibiting growth of some cancers [2]. Visible sunlight to the eyes gives health benefits through its association with timing of melatonin synthesis; maintenance of normal and robust cardiac rhythms and reduce the risk of seasonal affective disorder [3]. A daily requirement of vitamin $\mathrm{D}$ can be obtained by 30-60 min exposure to sunlight in the morning [4].

It is important to limit the sun exposure between the hours of $10 \mathrm{a} . \mathrm{m}$. and 4 p.m. for infants. In infants 1 week after birth the level of vitamin D is related to the level in their mothers during pregnancy [5]. The other source of

\footnotetext{
*Correspondence: asresbedaso@gmail.com
}

College of Medicine and Health Sciences, School of Nursing, Hawassa

University, Hawassa, Ethiopia vitamin $\mathrm{D}$ is from ingested diet and from supplements [6]. Adequate supplementation of vitamin D prevents low birth weight (LBW), birth asphyxia and deafness due to premature birth [7]. Studies worldwide identify lack of sun exposure as the main cause of rickets [8].

Rickets is a major public health problem in many countries of the world and it is common in children in SubSaharan African countries. Infants at risk of rickets are those whose mothers had poor vitamin D status during pregnancy and those exclusively breast-fed for a prolonged period with little skin exposure to ultraviolet $B$ (UVB) [9]. Rickets is usually manifests as skeletal abnormalities, including frontal bossing, craniotabes, widening wrist, bowed legs and rachitic rosary [10]. The major causes of nutritional rickets in Ethiopia is lack of exposure to sunshine and inadequate intake of vitamin D [11].

Inadequate sunlight exposure of infants combined with nutritional rickets continues to be an evolving problem with several causes [12]. Nutritional rickets has received considerable attention from public health specialists in a number of developed countries. In developing countries, 
attention has been focused on rickets because of its effect on bone growth and mineral homeostasis and because of its association with increased infant and childhood mortality especially when accompanying lower respiratory tract infections $[13,14]$.

Primary deficiency is highly prevalent, even in countries with abundant sunshine, when skin exposure to UVB sunlight is limited by lifestyle and other factors. In Ethiopia, a review of rickets stated that the prevalence of rickets was highly as $40 \%$, making it one of the highest in the world [15]. A study conducted in Kenyatta National Hospital showed that $58.8 \%$ of children aged 6 months develop rickets [16]. A recent study conducted in Kiambu District Hospital states that the prevalence of rickets in children 0-59 months to be $3.4 \%$ [17].

Until recently, little attention has been paid to the prevalence of rickets in most countries, but it is clear that rickets has been and remains a problem in Northern Asian countries, Middle East and in a number of countries in Africa [18]. A study done in Debre Markos 93\% of mothers exposed their infants to sunlight but only $57.9 \%$ of them exposed daily [19]. A review of pediatric admissions in Jimma hospital, south western Ethiopia indicated that about $10 \%$ of children were diagnosed has rickets [20].

Mothers' plays a key role in prevention of rickets by exposing their infants to sunlight adequately. Therefore, the objective of this study was to assess the knowledge and practice of adequate sunlight exposure of infants among mothers attending EPI unit at Aleta Wondo Health Center, Sidama zone, SNNPR, Ethiopia and fill the gap in these areas of concern.

\section{Main text \\ Methods \\ Study design, area and period}

An institutional based descriptive cross sectional study design was employed. Aleta Wondo is a town which is found in Sidama zone, SNNPR, Ethiopia. The town is located about $345 \mathrm{~km}$ away from Addis Ababa and $64 \mathrm{~km}$ from the regional capital city, Hawassa. This study was conducted from February 1 to April 30, 2018.

\section{Source population and study participants}

All mothers who attend EPI unit of Aleta Wondo health center for under one children EPI service were source population. All mothers who attend EPI unit of Aleta Wondo health center for under one children EPI service during the study period and fulfill the inclusion criterion were considered as study population.

\section{Sample size determination and sampling technique}

The sample size was calculated using a single population proportion formula by estimated prevalence of
$54 \%$ taken from the study conducted in Debre Markos Town [19], with 5\% marginal error (d) and confidence interval of $95 \%(Z \alpha / 2=1.96)$. Based on these assumptions and adding $10 \%$ non-response rate, the total estimated sample size was 312 .

Regarding sampling, first, we selected one health center among all health centers through simple random sampling technique. Finally, simple random sampling technique was used to select the required number of participants among those who fulfill the inclusion criteria.

\section{Inclusion and exclusion criteria}

Mothers who attend EPI unit of Aleta Wondo health center for under one children EPI service were included in the study. Mothers who have difficulty of communication (hearing problem) were excluded from the study.

\section{Data collection}

Structured and pre-tested questionnaires were used to collect data. The questionnaire had four parts such as socio demographic related question, knowledge related question, practice related question and other determinant factors. The data was collected by trained nurses.

\section{Data analysis}

Data was entered and statistical analysis was carried out using SPSS version 20. The collected data were presented by frequency and percentage using tables, bar graph and pie charts. Mean and standard deviation was computed for numerical variables.

\section{Operational definitions}

Adequate sunlight exposure: Those mothers who exposed their infants to sunshine at morning 8-10 a.m. for 15-30 min. Knowledgeable: those mothers who scored more than the mean value of response for knowledge related questions. Good Practice: Those mothers who scored more than the mean value of response for practice related questions.

\section{Result}

\section{Socio demographic characteristics}

All the required 313 study participants who came for EPI service at Aleta Wendo health center immunization clinic were interviewed with the response rate $100 \%$. $144(46.2 \%)$ of the respondents were between the ages of $22-27$ years and $256(82.1 \%)$ of their infants age were below 6 months. The mean age of the mothers and infants were 24 years and 4 months respectively (Table 1). 
Table 1 Socio-demographic characteristics of mothers who attend EPI service in Aleta Wendo Health Center, Aleta Wondo Town, Southern Ethiopia, 2018 ( $\mathrm{N}=312)$

\begin{tabular}{|c|c|c|c|}
\hline Variable & Category & Number & Percent (\%) \\
\hline \multirow[t]{4}{*}{ Mothers age } & $16-21$ & 119 & 38.1 \\
\hline & $22-27$ & 144 & 46.2 \\
\hline & $28-33$ & 43 & 13.8 \\
\hline & $34+$ & 6 & 1.9 \\
\hline \multirow[t]{2}{*}{ Infant's age } & $0-6$ months & 256 & 82.1 \\
\hline & 7-12 months & 56 & 17.9 \\
\hline \multirow[t]{4}{*}{ Religion } & Protestant & 205 & 65.7 \\
\hline & Orthodox & 65 & 20.8 \\
\hline & Muslim & 36 & 11.5 \\
\hline & Other & 6 & 2.0 \\
\hline \multirow[t]{4}{*}{ Ethnicity } & Sidama & 233 & 74.7 \\
\hline & Oromo & 33 & 10.6 \\
\hline & Amhara & 36 & 11.5 \\
\hline & Other & 10 & 3.2 \\
\hline \multirow[t]{4}{*}{ Marital status } & Single & 5 & 1.6 \\
\hline & Married & 298 & 95.5 \\
\hline & Divorced & 4 & 1.3 \\
\hline & Widowed & 5 & 1.6 \\
\hline \multirow[t]{6}{*}{ Mothers educational status } & Unable to read and write & 26 & 8.3 \\
\hline & Able to read and write & 11 & 3.5 \\
\hline & Grade 1-6 & 55 & 17.6 \\
\hline & Grade 7-10 & 147 & 47.1 \\
\hline & Grade 11-12 & 17 & 5.4 \\
\hline & Diploma and above & 56 & 17.9 \\
\hline \multirow[t]{3}{*}{ Family size } & $1-3$ & 146 & 46.8 \\
\hline & $4-6$ & 130 & 41.7 \\
\hline & $\geq 6$ & 36 & 11.5 \\
\hline \multirow[t]{6}{*}{ Mothers occupation } & Student & 12 & 3.8 \\
\hline & Housewife & 216 & 69.2 \\
\hline & Government employee & 49 & 15.7 \\
\hline & Private employee & 8 & 2.6 \\
\hline & Daily laborer & 5 & 1.6 \\
\hline & Merchant & 22 & 7.1 \\
\hline \multirow[t]{6}{*}{ Husbands educational status } & Unable to read and write & 22 & 7.1 \\
\hline & Able to read and write & 14 & 4.5 \\
\hline & Grade 1-6 & 27 & 8.6 \\
\hline & Grade 7-10 & 139 & 44.6 \\
\hline & Grade 11-12 & 26 & 8.3 \\
\hline & Diploma and above & 84 & 26.9 \\
\hline \multirow[t]{2}{*}{ Childhood history of common cold } & Yes & 167 & 53.5 \\
\hline & No & 145 & 46.5 \\
\hline \multirow[t]{2}{*}{ Childhood history of pneumonia } & Yes & 60 & 19.2 \\
\hline & No & 252 & 80.8 \\
\hline
\end{tabular}

\section{Maternal information about the need of sunlight exposure} of infants

Among the total respondents, majority 288 (92.3\%) of the mothers had information about the need of sunlight exposure for their infants and out of those mother who had information, half $148(51.0 \%)$ of mothers got the information from neighbors/elders (Fig. 1). 


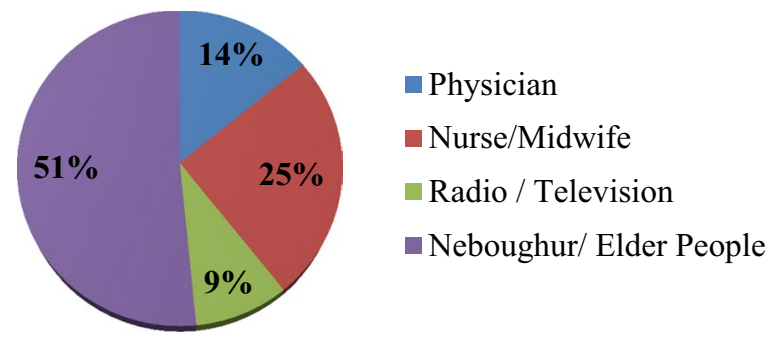

Fig. 1 Maternal source of information about the need of sunlight exposure of infants among who attend EPI service in Aleta Wendo Health Center, Aleta Wondo Town, Sidama zone, SNNPR, Ethiopia, $2018(n=288)$

\section{Maternal knowledge about sunlight exposure of infants}

From total respondents, 265 (84.9\%) of mothers reported that sunlight exposure had positive benefit for infants and from those mothers. Majority, 157 (59.3\%) of women's indicated that sunlight exposure was useful to strength bone. In the other side, nearly half 152 (48.7\%) of the study subjects indicated that sunlight exposure had negative or harmful effect on infant (Table 2).

\section{Mothers general knowledge about adequate sunlight exposure of infants}

The mean score value of mothers who had knowledge about sunlight exposure was 6 out of the total score 10 . More than half 196 (62.8\%) of the study participants were knowledgeable about sunlight exposure (Additional file 1).

\section{Practice of mothers about sunlight exposure of infants}

Out of the total respondents, 250 (80.1\%) of mothers exposed their infants to sunlight. Among the reasons for not exposing their infants to sunlight, 62 (19.9\%) of mothers said it is due to fear of cold and 19 (30.7\%) responded due to fear of evil eyes (Additional file 2).

\section{Age of infants for first sunlight exposure}

From all mothers who exposed their infants to sunlight, 75 (30\%) of mothers started exposing their infant to sun light at age of 45 days and above (Additional file 3).

\section{Mothers general practice level about adequate sunlight exposure of infants}

The mean score value of mothers who had practice of sunlight exposure of infants was 5 of the total score 10 . More than half 145 (58\%) of the study participants had good practice about adequate sunlight exposure (Additional file 4).

\section{Discussion}

In the current study, more than half $(62.8 \%)$ of the mothers were knowledgeable about of sunlight exposure for infants. In addition most of mothers (84.9\%) had awareness of the positive health benefit of sunlight exposure for infant and majority of them (59.3\%) indicated sunlight exposure as the most important source of vitamin $\mathrm{D}$ used for growth and strength of bone through mobilization of calcium in the body. Also, $65.4 \%$ of the mother had awareness about the effect of inadequate or absence of sunlight exposure in health status that leads to rickets. This finding was consistent with the study done in Turkey which indicated that exposure of infant for sunlight was beneficial for bone development, diaper rash and neonatal jaundice [21].

Concerning the health risk of solar UV radiation exposure, nearly half (48.7\%) of mothers believed that sunlight exposure had negative health effect as a result of improper time and duration of exposure, such as skin cancer and sun burn. This idea was also supported with a review of research done in Germany on the challenges resulting from positive and negative effects of sunlight [22]. This indicated that most of the mothers do not have enough information about healthy sun bathing and its effect since sun bathing might be also useful for treating neonatal jaundice, dipper rash and prevention of vitamin D deficiency related conditions like hypertensions, cardiovascular disease and bone disease etc [23].

Regarding practice of sunlight exposure, $58.0 \%$ of the study participants had good practice about adequate sunlight exposure who score more than or equal to mean score value. However, majority $(80.1 \%)$ of mothers were exposed their infants to sunlight. This finding was lower than similar study done in Debre Markos Town of Ethiopia which was 93\% [19]. The reason for the difference might be the difference in socio cultural factors like fear of illness, fear of evil eyes and witchcraft and level of appropriate information concerning sunning the baby.

In this study, only $17.6 \%$ of mothers were started sun light exposure of their infants between 0-15 days of neonatal life, which was lower than similar study done in Debre Markos town of Ethiopia which was 24\% [19]. However, $67.6 \%$ of mothers of this study were sunning their babies at daily which was better than the study done at Debre Markos town of Ethiopia which was $57.9 \%$ [19]. In addition, more than half (63.6\%) of the 
Table 2 Knowledge status of mothers about sunlight exposure of their infants among who attend EPI service in Aleta Wendo Health Center, Aleta Wondo Town, Southern Ethiopia, 2018 ( $N=312)$

\begin{tabular}{|c|c|c|c|}
\hline Variable & Categories & Number & Percent (\%) \\
\hline \multirow[t]{2}{*}{ Maternal positive belief towards the benefit of sunlight exposure of infants } & Yes & 265 & 84.9 \\
\hline & No & 47 & 15.1 \\
\hline \multirow[t]{5}{*}{ Benefit of sunlight exposure $(n=265)$} & Strengthen bone & 157 & 59.3 \\
\hline & Strengthen teeth & 18 & 6.8 \\
\hline & Strengthen body & 18 & 6.8 \\
\hline & Produce vitamin D & 56 & 21.1 \\
\hline & Keep child warm & 16 & 6.0 \\
\hline \multirow[t]{2}{*}{ Maternal perception harmfulness of sunlight exposure of infants } & Yes & 152 & 48.7 \\
\hline & No & 160 & 51.3 \\
\hline \multirow[t]{5}{*}{ Harmful effects of sunlight exposure $(N=152)$} & Skin cancer & 67 & 21.5 \\
\hline & Sun burn & 30 & 9.6 \\
\hline & Inflammation and Hyper pigmentation & 21 & 6.7 \\
\hline & Blindness & 26 & 8.3 \\
\hline & Sterility & 8 & 2.6 \\
\hline \multirow[t]{4}{*}{ Good time to expose infants to sunlight } & Morning time & 282 & 90.4 \\
\hline & After noon Time & 15 & 4.8 \\
\hline & Evening time & 8 & 2.6 \\
\hline & Any time & 7 & 2.2 \\
\hline \multirow{2}{*}{$\begin{array}{l}\text { Awareness about the effect of inadequate or absence of sunlight exposure } \\
\text { such as rickets }\end{array}$} & Yes & 204 & 65.4 \\
\hline & No & 108 & 34.6 \\
\hline \multirow[t]{7}{*}{ Awareness attribute to detection of rickets (sign of rickets) $(N=204)$} & Late closure of fontanel & 56 & 27.5 \\
\hline & Late tooth eruption & 18 & 8.8 \\
\hline & Bowing of leg & 63 & 30.9 \\
\hline & Enlargements of joints & 24 & 11.8 \\
\hline & Knock knee & 30 & 14.7 \\
\hline & Weak leg & 9 & 4.4 \\
\hline & Don't know & 4 & 2.0 \\
\hline \multirow[t]{3}{*}{ Knowledge attribute to prevention and/or curability of rickets $(N=204)$} & Yes & 156 & 76.4 \\
\hline & No & 35 & 17.2 \\
\hline & Don't know & 13 & 6.4 \\
\hline \multirow[t]{5}{*}{ Treatment or prevention option of rickets $(N=204)$} & Follow doctors advice & 107 & 52.5 \\
\hline & Early detection and treatment & 19 & 9.3 \\
\hline & Adequate Diet Intake & 25 & 12.2 \\
\hline & Sunbathing the child & 30 & 14.7 \\
\hline & Don't know & 23 & 11.3 \\
\hline
\end{tabular}

mothers exposed their babies in outdoor which were lower than the similar study done previously at Debre Markos town which was $89.4 \%$ [19].

Most of mothers (90.0\%) were exposed their babies between the time range of $8-10$ a.m. in this study, but $54.8 \%$ and $26.8 \%$ of mothers were sunning their babies without sun screening or clothing and with time duration of 15-30 min as recommended, respectively. This finding was slightly lower than the study done at Debre Markos on exposing without sun screening and time of exposure which accounts $57.3 \%$ and $99.1 \%$, respectively; whereas, its higher on duration of exposure which accounts $25.5 \%$ [19]. This study finding was also incomparable with similar study done in Dale woreda of Southern Ethiopia as shown that $41.1 \%$ of the mothers exposed their child to sunlight within 1 month of birth [24].

Most of the children were exposed to sunlight for 20 to 30 min per day. About $49.4 \%$ were exposed to sunlight for 7 days in a week and $90.0 \%$ children were exposed to sunlight without clothing.

In this study, most of the mothers (90.8\%) were used lubricants to be applied on their infant's body when 
exposed to sunlight. Beside this, $41.4 \%$ of mothers were applied lubricants during the time of sunlight exposure, and followed by mothers who were applied lubricant after sunlight exposure which accounts $38.7 \%$. This finding was lower than the same study done at Debre Markos town as shown that most (98.4\%) of respondents applied lubricants on the baby's body at the time of sunlight exposure and majority (70.6\%) of mothers apply during sunlight exposure [19].

\section{Conclusion}

Although majority of the respondents have good knowledge about importance of sunlight exposure for the infants but there is a gap on time to start sunlight exposure and time to stay on sunlight while exposing.

\section{Limitation of the study}

Since the study is cross sectional it does not show cause and effect relationship between dependent and independent variables.

\section{Additional files}

Additional file 1. Distribution of maternal general level of knowledge about sunlight exposure of their infants based of knowledge score among who attend EPI service in Aleta Wendo Health Center, Aleta Wondo Town, Southern Ethiopia , $2018(n=312)$

Additional file 2. Practice of mothers on adequate sunlight exposure of their infants among who attend EPI service in Aleta Wendo Health Center, Aleta Wondo Town, Southern Ethiopia, $2018(\mathrm{~N}=250)$.

Additional file 3. Age of infants who sunlight exposure among mothers who attend EPI service in Aleta Wondo Health Center, Aleta Wondo Town, Southern Ethiopia , 2018 ( $N=250)$

Additional file 4 General Practice of mothers among who expose their infants to sunlight and who attend EPI service in Aleta Wendo Health Center, Aleta Wondo Town, Sidama Zone, Southern Ethiopia, 2018 $(n=250)$

\section{Abbreviations}

Cl: confidence interval; EPI: expanded program immunization; LBW: low birth weight; SNNPR: Southern Nations Nationality and Peoples Region; SPSS: Statistical Package for Social Science; UV: ultra violet.

\section{Authors' contributions}

$A B, M G$ participated in the conception, design of the study, reviewing proposal and data analysis. $A B, M G, B D, M A$ and $B D$ participated in reviewing proposal and writing the research report. $A B$ prepared the manuscript for publication. MG and BD have participated in supervising and editing manuscript. All authors read and approved the final manuscript.

Acknowledgements

We would like to thank study participants and data collectors for their unreserved contribution.

\section{Competing interests}

The authors declare that they have no competing interests.
Availability of data and materials

All data are included in this article and its supporting document.

\section{Consent for publication}

Not applicable.

\section{Ethics approval and consent to participate}

Ethical clearance was obtained from ethical review board of Hawassa University, College of Medicine and health sciences. All participants of the study provided with a written consent, clearly stating the objectives of the study and the right of study participants. All participants were randomly selected without any discrimination and filled out questionnaires were carefully handled and all access to results kept strictly.

\section{Funding}

No funding was received for this research work.

\section{Publisher's Note}

Springer Nature remains neutral with regard to jurisdictional claims in published maps and institutional affiliations.

Received: 7 February 2019 Accepted: 25 March 2019

Published online: 29 March 2019

\section{References}

1. Reed K. 7 health benefits of direct sunlight to new born babies. Positive health wellness. 2017. https://www.positivehealthwellness.com/dietnutrition/7-health-benefits-direct-sunlight-newborn-babies/.

2. Horsley T, Cranney A, Donnel SO, Weiler H, Puil L, Ooi D. Effectiveness and safety of vitamin D in relation to bone health. Agency Healthc Res Qual. 2007:158:1-235.

3. Mead MN. Benefits of sunlight a bright spot for human health. Environ Health Perspect. 2008;116:160-7.

4. Teotia M, Teotia PS. Endemic flourosis and calcium deficiency interaction syndromes. In: Teotia PS, Teotia M, editors. Nutritional and metabolic bone and stone disease, 1st edition. New Delhi: CBS publisher and distributions; 2008. p. 361-67.

5. Nesby OD. Hypovitaminosis D prevalence and determinants among africanamerican and white women of a reproductive age. Am J Clin Nutr. 2002;76:3-4.

6. Calvo SM, Whiting J, Barton NS. Vitamin D intake: global perspective of current status.J Nutr. 2005:135:310-6.

7. Mahendra TK, VivekT. Roll of vitamin D prevention of deafness. Indian J Otol. 2012:18:55-7.

8. Holick MH. Vitamin D deficiency. N Eng J Med. 2007;357:266-81

9. Anthony N, Roger BDB. Nutritional rickets around the world. J Steroid Biochem Mol Biol. 2013;136:201-6.

10. Fukumoto S, Ozono K, Michigami T, Mingawa M, Okazaki R, Sugimoto T, Matsumoto T. Pathogenesis and diagnostic criteria for rickets and osteomalacia_-proposal by an expert panel supported by ministry of health, labour and welfare. Jpn Endocr Soc Endocr J. 2015;62(8):665-71.

11. Woldemichael K, Berhanu N. Magnitude and pattern of injury in Jimma University Specialized Hospital, South West Ethiopia. Ethiop J Health Sci. 2011;21(3):155-65.

12. Creo AL, Thacher TD, Pettifor JM, Strand MA, Fischer P. Nutritional rickets around the world: an update. Paediatr Int Child Health 2017;37(2):84-988.

13. Ganmaa D, Stuart JJ, Sumberzul N, Ninjin B, Giovannuci E, Kleinman K, Rich-Edwards JW. Vitamin D supplementation and growth in urban Mongol school children: results from two randomized clinical trials. PLoS ONE. 2017;12(5):e0175237.

14. Thacher TD, Fischer PR, Strand MA, Pettifor J. Nutritional rickets around the world: causes and future directions. Ann Trop Paediatr. 2006;26:1-16.

15. Prentice A. Vitamin D deficiency: a global perspective. Nutr Rev. 2008;66:S153-S164164.

16. Oyatsi DP, Musoke RN, Wasunna A. Incidence of rickets of prematurity at Kenyattav National Hospital, Nairobi. East Afr Med J. 1999;76(2):63-6. 
17. Theuri Alice W. Factors associated with rickets among children aged 0-59 months at Kiambu District Hospital. Kenya: University of Nairobi research archive; 2012. p. 16-22. http://erepository.uonbi.ac.ke:8080/xmlui/handl e/123456789/6793.

18. Pettifor MJ. Nutritional rickets and vitamin D deficiency in nutrition and health in developing countries. 2nd ed. Totowa: Humana Press; 2008. p. 435-454.

19. Abate A, Murugan R, Gualu T. Assessment of practice and factors affecting sunlight exposure of infants among mothers attending governmental health facilities in Debre Markos town, East Gojjam, Ethiopia. Am J Nurs Sci. 2015;5(1):30-6.

20. Kenenisa $\mathrm{C}$, Ewnetu H, Sime H. Retrospective analysis of prevalence of rickets and associated factors among children admitted to pediatric ward in Jimma University specialized hospital. J Pediatr Neonatal Care 2014;1(7):00044
21. Aladag N, FilizTM, Topsever P, Gorpelioglu S. Parents' knowledge and behaviour concerning sunning their babies; a cross-sectional, descriptive study. BMC Pediatr. 2006;6(27):1-6.

22. Reichrath J. The challenge resulting from positive and negative effects of sunlight: how much solar UV exposure is appropriate to balance between risks of vitamin D deficiency and skin cancer? Progress Biophys Mol Biol. 2006;92:9-16.

23. Zhang $X$, Ding F, Li H, Zhao W, Jing H, Yan Y, Chen Y. Low serum levels of vitamin $\mathrm{D}$ and are associated with recurrent respiratory tract infections in children living in northern China: a case control study. PLOS ONE. 2016;11(12):e0167689.

24. Tezera F, Whiting SJ, Gebremedhin S. Dietary calcium intake and sunlight exposure among children aged 6-23 month Sin Dale Woreda, Southern Ethiopia. Afr J Food Agric Nutr Dev. 2017;17(3):12427-400.
Ready to submit your research? Choose BMC and benefit from:

- fast, convenient online submission

- thorough peer review by experienced researchers in your field

- rapid publication on acceptance

- support for research data, including large and complex data types

- gold Open Access which fosters wider collaboration and increased citations

- maximum visibility for your research: over $100 \mathrm{M}$ website views per year

At BMC, research is always in progress.

Learn more biomedcentral.com/submissions 